\title{
Vitamins $E$ and C Supplementation in Japanese Quail: Effects on Growth Performance and Biochemical and Haematological Parameters
}

http://dx.doi.org/10.1590/1806-9061-2020-1269

-Author(s)

Khazaei R' (iD https://orcid.org/0000-0001-7666-4944 Requena F" (iD https://orcid.org/0000-0001-7890-2635 Seidavi A' (ID) https://orcid.org/0000-0002-1903-2753 Martínez AL"I (iD) https://orcid.org/0000-0003-0052-9724

Islamic Azad University, Rasht Branch, Department of Animal Science, Rasht, Iran, P.O. Box 413353516

" Universidad de Córdoba, Departamento de Biología Celular, Fisiología e Inmunología Campus Universitario de Rabanales, Ctra MadridCádiz, km 396, 14071 Córdoba, Spain

III Universidad de Córdoba, Departamento de Producción Animal, Campus Universitario de Rabanales, Ctra Madrid-Cádiz, km 396, 14071 Córdoba, Spain

\section{a Mail Address}

Corresponding author e-mail address Alireza Seidavi

Islamic Azad University, Rasht Branch, Department of Animal Science, Rasht, Iran, P.O. Box 41335-3516

Phone: +989113313073

Email: alirezaseidavi@iaurasht.ac.ir

\section{EKeywords}

Antioxidant, quail, stress, vitamin.

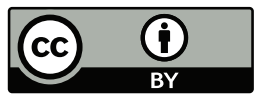

Submitted: 27/August/2020 Approved: 28/December/2020

\section{ABSTRACT}

The effects of vitamins $E$ and $C$ supplementation on growth performance and biochemical and haematological parameters of Japanese quail were studied. A total of 360 one-day-old Japanese female quails were randomly allocated to nine dietary treatment groups (10 birds per replicate and 4 replicates per treatment), including a control (basal diet) and the basal diet supplemented with: 250 or 500 $\mathrm{mg} / \mathrm{kg}$ of vitamin C, 250 or $500 \mathrm{mg} / \mathrm{kg}$ of vitamin E, $250 \mathrm{mg} / \mathrm{kg}$ of both vitamins $E$ and $C, 250$ and $500 \mathrm{mg} / \mathrm{kg}$ of vitamins $E$ and $C, 500$ and $250 \mathrm{mg} / \mathrm{kg}$ of vitamins $E$ and $C$, and $500 \mathrm{mg} / \mathrm{kg}$ of both vitamins $E$ and $C$. Vitamin supplementation improved productive parameters and raised the blood plasma levels of protein, thyroid-stimulating hormone, calcium and phosphorus, while decreased those of glucose, uric acid, creatinine and triglycerides, as well as lowered the activities of aspartate aminotransferase, alanine aminotransferase and alkaline phosphatase. Leukocyte count as well as the heterophil to lymphocyte ratio decreased and red blood cell count increased in the supplemented groups. The results obtained support that the simultaneous supplementation with vitamins $\mathrm{E}$ and $\mathrm{C}$ has greater positive effects on growth performance, metabolism indicators and haematological parameters than their supplementation separately, which in turn shows improvements over the absence of supplementation.

\section{INTRODUCTION}

During intensive production processes, birds are exposed to several factors of stress that can enhance oxidative stress and suppress immune system, with consequent negative effects on the productive performance and increased economic losses for producers. Diet supplementation with vitamins $\mathrm{E}$ or $\mathrm{C}$ has shown beneficial effects on productive and reproductive results of poultry under stressful conditions (Khan et al., 2011 \& 2012). Those results may be related to the common observation that supplementation with vitamin E or vitamin C significantly improves the antioxidant ability and immune performance, as well as alleviates the increased expression of inflammatory cytokines, counteracting the effects of corticosteroids released during stress (Jang et al., 2014; Min et al., 2018).

Most studies with Japanese quails supplemented with vitamins $E$ and/or $C$ have been carried out under heat stress conditions (Sahin et al., 2002; Ferit Gursu et al., 2003 and 2004; Seyrek et al., 2004; Ipek et al., 2006 and 2007; Imik et al., 2009) and some other at low ambient temperature (Sahin et al., 2003; Shah et al., 2016). However, there is little information on supplementation in the absence of any specific stressor (Şenay et al., 2019; Sigolo et al., 2019) and comparing the findings to a non-supplemented control group. Thus, the aim of the 
present study was to evaluate the effects of vitamins $\mathrm{E}$ and $\mathrm{C}$ supplementation, separately or combined, on the growth performance and biochemical and haematological parameters of Japanese quails reared under typical on-farm conditions, without environmental stressful conditions.

\section{MATERIAL AND METHODS}

The current study was conducted at a commercial quail farm (Amol, Iran). Use and care of birds and procedures employed on this study were approved by the Animal Care and Welfare Committee of Islamic Azad University (authorization number 1395).

The experimental period was 42 days. A total of 360 one-day-old Japanese female quails were randomly allocated to nine dietary treatment groups. The dietary treatments were replicated four times each with ten birds per replicate. Each replicate was housed in a ground cage $(0.70 \mathrm{~m} \times 0.50 \mathrm{~m})$ provided with a nipple waterer and a feeder. During raising period, the temperature was initially set at $37^{\circ} \mathrm{C}$ and gradually reduced at a rate of $3^{\circ} \mathrm{C} /$ week until the fifth week. The relative humidity was 55\%-65\%. The lighting programme consisted of $17 \mathrm{~h}$ of light and $7 \mathrm{~h}$ of dark and water and diets were offered for ad libitum consumption throughout the experimental period.

The basal diet was based on maize and soybean meal (Table 1) and was supplemented with vitamin $\mathrm{E}$ (DL- $\alpha$-tocopheryl acetate) and/or vitamin C (L-ascorbic acid) at two different levels to obtain the following treatments:

-Control: basal diet (vitamin premix supplied $10 \mathrm{mg} /$ $\mathrm{kg}$ of vitamin $\mathrm{E}$ and no vitamin $\mathrm{C}$ ).

-OE-250C: control supplemented with $250 \mathrm{mg} / \mathrm{kg}$ of vitamin $C$.

$-0 \mathrm{E}-500 \mathrm{C}$ : control supplemented with $500 \mathrm{mg} / \mathrm{kg}$ of vitamin C.

-250E-0C: control supplemented with $250 \mathrm{mg} / \mathrm{kg}$ of vitamin $E$.

-500E-0C: control supplemented with $500 \mathrm{mg} / \mathrm{kg}$ of vitamin $E$.

-250E-250C: control supplemented with $250 \mathrm{mg} /$ $\mathrm{kg}$ of both vitamins $\mathrm{E}$ and $\mathrm{C}$.

-250E-500C: control supplemented with $250 \mathrm{mg} /$ $\mathrm{kg}$ of vitamin $\mathrm{E}$ and $500 \mathrm{mg} / \mathrm{kg}$ of vitamin $C$.

-500E-250C: control supplemented with 500 mg/ $\mathrm{kg}$ of vitamin $\mathrm{E}$ and $250 \mathrm{mg} / \mathrm{kg}$ of vitamin C.

-500E-500C: control supplemented with 500 mg/ $\mathrm{kg}$ of both vitamins $\mathrm{E}$ and $\mathrm{C}$.
Table 1 - Experimental diet fed to Japanese quails during the experimental period ( 1 to 42 days of age).

\begin{tabular}{lc}
\hline Composition & $\%$ as fed \\
\hline Ingredients (\%) & 60.29 \\
Maize & 34.50 \\
Soybean meal 44\% protein & 2.06 \\
Soybean oil & 0.35 \\
Salt & 1.00 \\
Limestone & 1.31 \\
Dicalcium phosphate & 0.30 \\
Vitamin and mineral premix ${ }^{1}$ & 0.14 \\
\hline DL-methionine & 0.05 \\
\hline Choline (70\%) & \\
\hline Calculated analysis & 2900 \\
\hline Metabolizable energy (kcal/kg) & 20 \\
Crude protein (\%) & 0.85 \\
Calcium (\%) & 0.30 \\
Available phosphorus (\%) & 0.45 \\
Methionine (\%) & 0.76 \\
\hline Methionine + cysteine (\%) & 1.07 \\
\hline Lysine (\%) & \\
\hline
\end{tabular}

'Supplied per kg of feed: Cu: 8 mg; Fe: 50 mg; Mn: 70 mg; Zn: 50 mg; I: 1.2 mg; Se: $0.2 \mathrm{mg}$; vitamin A: 14,000 IU; vitamin D3: 4,000 IU; vitamin E: 10 mg; vitamin K3: 3.2 mg; riboflavin: $6 \mathrm{mg}$; cyanocobalamin: $16 \mathrm{mcg}$; niacin: $40 \mathrm{mg}$; pantothenic acid: $10 \mathrm{mg}$.

Supplemented diets were prepared weekly and stored in polypropylene ventilated bags, which were kept on wooden pallets at ambient temperature and protected from sunlight. Feeders were refilled daily.

Body weight and feed consumption were weekly recorded by cage, and body weight gain (g/period), feed intake (g/period), and feed conversion ratio (feed to gain $\mathrm{g} / \mathrm{g}$ ) were determined.

On the last day of the experiment, four quails per treatment (one from each replicate) that had weights closest to the mean weight for the cage were selected to collect blood from their wing veins into duplicate EDTA tubes, one for biochemical analyses and the other for haematological measures. Sampling was made after $4 \mathrm{~h}$ of fasting. Biochemical analyses were done according to standard protocols by using commercial laboratory kits (Pars Azmoon Co., Tehran, Iran) in plasma harvested after centrifuging blood samples (3000 g, for $10 \mathrm{~min}$ at room temperature). Glucose, total protein, albumin, uric acid, triglycerides, aspartate aminotransferase, alanine aminotransferase, alkaline phosphatase, thyroid-stimulating hormone, creatinine, calcium and phosphorus were determined in plasma. A semi-automatic cell counter (F-820, Sysmex, Dubai, UAE) was used for evaluation of haematological parameters, including total leukocytes, heterophils, neutrophils, lymphocytes, monocytes, eosinophils, basophils, red blood cells, haemoglobin and mean corpuscular haemoglobin concentration. 
The GLM procedure of SAS UE 3.5 (SAS Institute Inc., Cary, NC) was used in the statistical analyses of data. The statistical model was a $2 \times 3$ factorial design with two vitamins ( $E$ and $C$ ) and three levels of supplementation $(0,250$ and $500 \mathrm{mg} / \mathrm{kg}$ ) plus a control. Tukey's test was used to compare the least squares means. The responses to vitamin supplementation were also investigated through preplanned orthogonal contrasts between groups of treatments (C-only group vs. E-only group vs. C\&E group). Statistical significance was declared at $p<0.05$.

\section{RESULTS AND DISCUSSION}

The effects of diet supplementation with different levels of vitamins $E$ and $C$ and their combination on performance traits are presented in Table 2. Feed conversion rate was better $(p<0.05)$ in the $E \& C$ supplemented treatments compared with all the other treatments. Overall, the E\&C group performed better $(p<0.05)$ in terms of final body weight, body weight gain and feed conversion rate than the only- $C$ and only-E groups. A vitamin $E \times C$ interaction effect $(p<0.05)$ was observed on all the parameters. The highest final body weight and body weight gain $(p<0.05)$ were observed in the 500E-500C treatment followed by the 250E-500C treatment, and the lowest values $(p<0.05)$ were found in the control treatment followed by the $0 \mathrm{E}-250 \mathrm{C}$ and $250 \mathrm{E}-0 \mathrm{C}$ treatments, the three of them also showing the lowest feed intake $(p<0.05)$. In the only-C and E\&C groups, increasing the level of vitamin $C$ raised final body weight and body weight gain $(p<0.05)$, but feed conversion rate was only improved $(p<0.05)$ when the level of vitamin $C$ was augmented within the E\&C group, at any of the two levels of vitamin E. Within the only-E group, final body weight, body weight gain and feed intake were higher $(p<0.05)$ at the highest level of vitamin $\mathrm{E}$. Within the E\&C group, raising the level of vitamin $E$ had no effect $(p>0.05)$ on any of the measured variables when vitamin C was supplemented at $250 \mathrm{mg} / \mathrm{kg}$, but final body weight and body weigh gain increased $(p<0.05)$ when vitamin $C$ was supplemented at 500 $\mathrm{mg} / \mathrm{kg}$. Therefore, increasing the level of vitamin C from 250 to $500 \mathrm{mg} / \mathrm{kg}$ was favourable for final body weight and body weight gain regardless the level of vitamin $\mathrm{E}$, but to further improve feed conversion rate at least $250 \mathrm{mg} / \mathrm{kg}$ of supplementary vitamin E were needed. On the other hand, $500 \mathrm{mg} / \mathrm{kg}$ of vitamin $\mathrm{E}$ improved final body weight and body weight gain as compared to $250 \mathrm{mg} / \mathrm{kg}$ when supplemented alone or in combination with $500 \mathrm{mg}$ of vitamin C. Our results agree with those of Ipek et al. (2006) and Sigolo et al. (2019) and might be explained by an improved general body metabolism due to an alleviating effect of vitamins $\mathrm{E}$ and $\mathrm{C}$ on cellular damage of tissues by oxidants and inflammatory cytokines (Jang et al., 2014; Min et al., 2018).

Table 2 - Effects of vitamin E and/or vitamin C supplementation on growth performance of Japanese quails at 42 days of age.

\begin{tabular}{|c|c|c|c|c|c|c|c|c|c|c|c|c|c|}
\hline \multirow[b]{2}{*}{ Parameter } & \multicolumn{9}{|c|}{ Treatments } & & \multicolumn{3}{|c|}{ Probability } \\
\hline & Control & $\begin{array}{c}\text { OE- } \\
250 C\end{array}$ & $\begin{array}{c}\text { OE- } \\
500 C\end{array}$ & $\begin{array}{l}\text { 250E- } \\
\text { OC }\end{array}$ & $\begin{array}{l}500 \mathrm{E}- \\
0 \mathrm{C}\end{array}$ & $\begin{array}{l}250 \mathrm{E}- \\
250 \mathrm{C}\end{array}$ & $\begin{array}{l}250 \mathrm{E}- \\
500 \mathrm{C}\end{array}$ & $\begin{array}{l}\text { 500E- } \\
250 C\end{array}$ & $\begin{array}{l}\text { 500E- } \\
500 C\end{array}$ & SEM & $\begin{array}{c}\text { Only-C vs. } \\
\text { only-E }\end{array}$ & $\begin{array}{c}\text { Only-C vs. } \\
\text { C\&E }\end{array}$ & $\begin{array}{c}\text { Only-E vs. } \\
\text { C\&E }\end{array}$ \\
\hline Final body weight (g) & $192^{f}$ & $193^{e}$ & $196^{d}$ & $192^{\mathrm{ef}}$ & $195^{d}$ & $197 c$ & $200^{b}$ & $198^{c}$ & $201^{a}$ & 0.5 & $<0.05$ & $<0.05$ & $<0.05$ \\
\hline Body weight gain (g) & $4.36^{9}$ & $4.39^{e f}$ & $4.44^{d}$ & $4.37^{\mathrm{fg}}$ & $4.42^{\mathrm{de}}$ & $4.48^{c}$ & $4.54^{b}$ & $4.50^{c}$ & $4.58^{a}$ & 0.011 & $<0.05$ & $<0.05$ & $<0.05$ \\
\hline Feed intake (g) & $17.4^{\mathrm{d}}$ & $17.6^{\mathrm{cd}}$ & $17.7^{\mathrm{abc}}$ & $17.5^{\mathrm{cd}}$ & $17.8^{\mathrm{a}}$ & $17.6^{\mathrm{abc}}$ & $17.6^{\mathrm{bc}}$ & $17.7^{\mathrm{ab}}$ & $17.6^{\mathrm{abc}}$ & 0.02 & 0.68 & 0.58 & 0.94 \\
\hline Feed conversion rate $(\mathrm{g} / \mathrm{g}$ ) & $3.99^{\mathrm{a}}$ & $4.00^{\mathrm{a}}$ & $3.98^{\mathrm{ab}}$ & $4.01^{\mathrm{a}}$ & $4.01^{a}$ & $3.94^{\mathrm{bc}}$ & $3.87^{d}$ & $3.94^{c}$ & $3.85^{d}$ & 0.009 & $<0.05$ & $<0.05$ & $<0.05$ \\
\hline
\end{tabular}

OE-250C and OE-500C: control diet supplemented with 250 or $500 \mathrm{mg} / \mathrm{kg}$ of vitamin C. $250 \mathrm{E}-0 \mathrm{C}$ and 500E-OC: control diet supplemented with $250 \mathrm{or} 500 \mathrm{mg} / \mathrm{kg}$ of vitamin E. $250 \mathrm{E}-$ 250C, 250E-500C, 500E-250C, 500E-500C: control diet supplemented with $250 \mathrm{mg} / \mathrm{kg}$ of both vitamins E and C, 250 and $500 \mathrm{mg} / \mathrm{kg}$ of vitamins E and C, 500 and $250 \mathrm{mg} / \mathrm{kg}$ of vitamins $E$ and $C$, and $500 \mathrm{mg} / \mathrm{kg}$ of both vitamins $E$ and $C$, respectively.

SEM: standard error of the mean.

For each parameter, least squares means without a common superscript are significantly different $(p<0.05)$ between treatments by Tukey's test.

With regard to the biochemical indicators of metabolism changes due to stress, the only- $C$ group increased protein level and decreased glucose, triglyceride and uric acid levels in comparison with the only-E group $(p<0.05)$, and the E\&C group had larger effects on those variables than both of them $(p<0.05)$ (Table 3). For all the indicators, a vitamin $\mathrm{E} \times \mathrm{C}$ interaction effect $(p<0.05)$ existed. The most favourable values (i.e., low glucose, triglycerides and uric acid, and high total protein and albumin contents in blood plasma) were observed in the 250E-500C and 500E-500C treatments $(p<0.05)$, while the worst values were found in the control treatment $(p<0.05)$. Increasing the level of vitamin $C$ from 250 to $500 \mathrm{mg} / \mathrm{kg}$ decreased glucose levels $(p<0.05)$ regardless the level of vitamin $\mathrm{E}$, but total protein content was increased and uric acid and triglyceride contents were decreased $(p<0.05)$ only when vitamin $\mathrm{E}$ was simultaneously supplemented. 
Increasing the level of vitamin E from 250 to $500 \mathrm{mg} /$ $\mathrm{kg}$ decreased $(p<0.05)$ uric acid content within the only-E group and raised the albumin content within the E\&C group $(p<0.05)$ irrespective of the level of vitamin $C$. These results suggest lower gluconeogenesis and lipolysis and higher protein anabolism in agreement with the observed productive results and may be ascribed to a counteracting effect of the combined supplementation with vitamins $E$ and $C$, especially at the highest level of vitamin $C$, on the production of corticosteroids (Scanes, 2016). Furthermore, a general improvement of organ function and body growth would be supported by the lower level of creatinine, the lower activities of aspartate aminotransferase, alanine aminotransferase and alkaline phosphatase, and the higher level of thyroid-stimulating hormone in the E\&C group, with an outstanding effect in the 500E-500C treatment $(p<0.05)$ (Table 3$)$. Other authors have also reported better values in one or more metabolism indicators after dietary supplementation with vitamins E and/or C (Sahin et al., 2002; Ferit Gursu et al., 2003; Seyrek et al., 2004; Imik et al., 2009; Şenay et al., 2019), the results being more evident at the highest levels of inclusion (Sigolo et al., 2019).

The blood plasma contents of calcium and phosphorus were higher in the E\&C group than in the
only-C group $(p<0.05)$, which in turn was superior to the only-E group $(p<0.05)$ (Table 3$)$. A vitamin $E \times C$ interaction effect $(p<0.05)$ was found. The $500 \mathrm{E}-500 \mathrm{C}$ treatment displayed the highest values $(p<0.05)$ of calcium and phosphorus, while the lowest content of calcium was found in the control treatment and the lowest content of phosphorus was observed in the control and 250E-0C treatments, with all the other treatments in intermediate positions. Increasing the level of vitamin C from 250 to $500 \mathrm{mg} / \mathrm{kg}$ was only able to rise simultaneously calcium and phosphorus contents $(p<0.05)$ when supplemented in combination with $500 \mathrm{mg} / \mathrm{kg}$ of vitamin $\mathrm{E}$, whereas increasing the level of vitamin $E$ raised calcium and phosphorus contents $(p<0.05)$ when supplemented alone or together with $500 \mathrm{mg} / \mathrm{kg}$ of vitamin C. Calcium and phosphorus responses were in agreement with previous works (Sahin et al., 2002; Ferit Gursu et al., 2003; Seyrek et al., 2004). Vitamins E and C are directly involved in calcium and phosphorus absorption from the gut because they are needed for vitamin D metabolism (Cantatore et al., 1991; Norazlina et al., 2005) and any inhibitory effect on corticosteroid production would also enhance intestinal absorption and decrease urinary excretion of calcium (Virden \& Kidd, 2009).

Table 3 - Effects of supplementation with vitamin E and/or vitamin C on blood plasma constituents of Japanese quails at 42 days of age.

\begin{tabular}{|c|c|c|c|c|c|c|c|c|c|c|c|c|c|}
\hline \multirow[b]{2}{*}{ Parameter } & \multicolumn{9}{|c|}{ Treatments } & \multicolumn{4}{|c|}{ Probability } \\
\hline & Control & $\begin{array}{c}\text { OE- } \\
250 C\end{array}$ & $\begin{array}{l}\text { OE- } \\
500 C\end{array}$ & $\begin{array}{l}250 E- \\
0 C\end{array}$ & $\begin{array}{l}\text { 500E- } \\
\text { OC }\end{array}$ & $\begin{array}{l}250 \mathrm{E}- \\
250 \mathrm{C}\end{array}$ & $\begin{array}{l}250 \mathrm{E}- \\
500 \mathrm{C}\end{array}$ & $\begin{array}{l}500 \mathrm{E}- \\
250 \mathrm{C}\end{array}$ & $\begin{array}{l}500 E- \\
500 C\end{array}$ & SEM & $\begin{array}{l}\text { Only-C } \\
\text { vs. } \\
\text { only-E }\end{array}$ & $\begin{array}{c}\text { Only-C } \\
\text { vs. } \\
\text { C\&E }\end{array}$ & $\begin{array}{c}\text { Only-E } \\
\text { vs. } \\
\text { C\&E }\end{array}$ \\
\hline Glucose (mg/dL) & $293^{a}$ & $278^{b}$ & $267^{c}$ & $284^{b}$ & $283^{b}$ & $254^{d}$ & $244^{e}$ & $252^{d}$ & $240^{e}$ & 1.6 & $<0.05$ & $<0.05$ & $<0.05$ \\
\hline Total protein $(\mathrm{g} / \mathrm{dL})$ & $6.90^{e}$ & $7.90^{\text {cd }}$ & $8.10^{c}$ & $7.00^{e}$ & $7.51^{d}$ & $8.40^{\mathrm{bc}}$ & $9.07^{a}$ & $8.85^{a b}$ & $9.20^{\mathrm{a}}$ & 0.108 & $<0.05$ & $<0.05$ & $<0.05$ \\
\hline Albumin (g/dL) & $1.50^{e}$ & $1.67^{d}$ & $1.70^{d}$ & $2.08^{c}$ & $2.19 c$ & $2.50^{\mathrm{b}}$ & $2.42^{b}$ & $2.67^{a}$ & $2.74^{\mathrm{a}}$ & 0.018 & $<0.05$ & $<0.05$ & $<0.05$ \\
\hline Uric acid (mg/dL) & $7.30^{\mathrm{a}}$ & $6.55^{\mathrm{cd}}$ & $6.33^{\text {de }}$ & $6.95^{b}$ & $6.70^{c}$ & $6.22^{\text {ef }}$ & $5.71^{\mathrm{g}}$ & $6.08^{f}$ & $5.64^{9}$ & 0.052 & $<0.05$ & $<0.05$ & $<0.05$ \\
\hline Triglycerides (mg/dL) & $314^{a}$ & $271^{c}$ & $266^{\mathrm{cd}}$ & $296^{b}$ & $287^{b}$ & $258^{\text {de }}$ & $236^{f}$ & $251^{e}$ & $233^{f}$ & 1.8 & $<0.05$ & $<0.05$ & $<0.05$ \\
\hline Creatinine $(\mathrm{mg} / \mathrm{dL})$ & $1.92^{\mathrm{a}}$ & $1.07 c$ & $0.96^{c}$ & $1.86^{\mathrm{a}}$ & $1.88^{\mathrm{a}}$ & $1.12^{c}$ & $0.95^{c}$ & $1.33^{b}$ & $0.72^{d}$ & 0.036 & $<0.05$ & 0.65 & $<0.05$ \\
\hline Aspartate aminotransferase (IU/L) & $166^{a}$ & $161^{\mathrm{ab}}$ & $165^{\mathrm{a}}$ & $159^{b c}$ & $158^{b c}$ & $154^{\mathrm{cd}}$ & $154^{\mathrm{cd}}$ & $153^{\mathrm{cd}}$ & $149^{d}$ & 1.4 & $<0.05$ & $<0.05$ & $<0.05$ \\
\hline Alanine aminotransferase (IU/L) & $48.4^{a}$ & $46.7^{\mathrm{ab}}$ & $45.8^{b c}$ & $43.4^{\mathrm{cd}}$ & $42.9^{d}$ & $41.8^{\text {de }}$ & $41.2^{\text {de }}$ & $40.2^{\text {ef }}$ & $38.2^{f}$ & 0.52 & $<0.05$ & $<0.05$ & $<0.05$ \\
\hline Alkaline phosphatase (IU/L) & $191^{\mathrm{a}}$ & $179^{b}$ & $187^{a}$ & $166^{c}$ & $164^{c}$ & $142^{d}$ & $133^{e}$ & $133^{e}$ & $125^{f}$ & 1.4 & $<0.05$ & $<0.05$ & $<0.05$ \\
\hline $\begin{array}{l}\text { Tyroid-stimulating } \\
\text { hormone (mIU/mL) }\end{array}$ & $0.119^{h}$ & $0.146^{g h}$ & $0.271^{\mathrm{fg}}$ & $0.388^{f}$ & $0.767^{e}$ & $0.986^{d}$ & $1.164^{c}$ & $1.439^{b}$ & $1.682^{\mathrm{a}}$ & 0.0275 & $<0.05$ & $<0.05$ & $<0.05$ \\
\hline Calcium (mg/dL) & $9.3^{9}$ & $11.6^{\text {de }}$ & $11.8^{\mathrm{cd}}$ & $10.3^{f}$ & $11.2^{\mathrm{e}}$ & $12.1^{\mathrm{cd}}$ & $12.9^{b}$ & $12.2^{c}$ & $13.7^{a}$ & 0.11 & $<0.05$ & $<0.05$ & $<0.05$ \\
\hline Phosphorus (mg/dL) & $7.22^{f}$ & $8.54^{d}$ & $8.65^{\mathrm{cd}}$ & $7.42^{f}$ & $7.77^{e}$ & $8.75^{b c}$ & $8.88^{b}$ & $8.78^{b c}$ & $9.78^{a}$ & 0.043 & $<0.05$ & $<0.05$ & $<0.05$ \\
\hline
\end{tabular}

OE-250C and OE-500C: control diet supplemented with 250 or $500 \mathrm{mg} / \mathrm{kg}$ of vitamin C. $250 \mathrm{E}-0 \mathrm{C}$ and $500 \mathrm{E}-0 \mathrm{C}$ : control diet supplemented with 250 or $500 \mathrm{mg} / \mathrm{kg}$ of vitamin $\mathrm{E}$. 250E-250C, 250E-500C, 500E-250C, 500E-500C: control diet supplemented with $250 \mathrm{mg} / \mathrm{kg}$ of both vitamins E and C, 250 and $500 \mathrm{mg} / \mathrm{kg}$ of vitamins E and C, 500 and $250 \mathrm{mg} /$ $\mathrm{kg}$ of vitamins $E$ and $\mathrm{C}$, and $500 \mathrm{mg} / \mathrm{kg}$ of both vitamins $E$ and $\mathrm{C}$, respectively.

SEM: standard error of the mean.

For each parameter, least squares means without a common superscript are significantly different $(p<0.05)$ between treatments by Tukey's test.

Haematological parameters are shown in Table 4. The response to vitamin supplementation was clearer in the E\&C group except for monocytes, eosinophils and basophils $(p<0.05)$. All haematological parameters showed a vitamin $E \times C$ interaction $(p<0.05)$. The highest counts of leucocytes, heterophils, neutrophils, 
Table 4 - Effects of supplementation with vitamin E and/or vitamin C on haematological parameters of Japanese quails at 42 days of age

\begin{tabular}{|c|c|c|c|c|c|c|c|c|c|c|c|c|c|}
\hline \multirow[b]{2}{*}{ Parameter } & \multicolumn{9}{|c|}{ Treatments } & \multicolumn{4}{|c|}{ Probability } \\
\hline & Control & $\begin{array}{l}\text { OE- } \\
250 C\end{array}$ & $\begin{array}{l}\text { OE- } \\
500 C\end{array}$ & $\begin{array}{l}250 \mathrm{E}- \\
0 \mathrm{C}\end{array}$ & $\begin{array}{l}500 \mathrm{E}- \\
0 \mathrm{C}\end{array}$ & $\begin{array}{l}250 \mathrm{E}- \\
250 \mathrm{C}\end{array}$ & $\begin{array}{l}250 \mathrm{E}- \\
500 \mathrm{C}\end{array}$ & $\begin{array}{l}500 \mathrm{E}- \\
250 \mathrm{C}\end{array}$ & $\begin{array}{l}500 \mathrm{E}- \\
500 \mathrm{C}\end{array}$ & SEM & $\begin{array}{c}\text { Only-C } \\
\text { vs. } \\
\text { only-E }\end{array}$ & $\begin{array}{c}\text { Only-C } \\
\text { vs. } \\
\text { C\&E }\end{array}$ & $\begin{array}{c}\text { Only-E } \\
\text { vs. } \\
\text { C\&E }\end{array}$ \\
\hline Leukocytes $\left(10^{9} / \mathrm{L}\right)$ & $9.51^{a}$ & $9.13^{d}$ & $9.16^{d}$ & $9.26^{c}$ & $9.37^{b}$ & $9.09^{\text {de }}$ & $9.06^{\mathrm{ef}}$ & $9.12^{\text {de }}$ & $9.02^{f}$ & 0.015 & $<0.05$ & $<0.05$ & $<0.05$ \\
\hline Heterophils $\left(10^{3} / \mathrm{mL}\right)$ & $28.1^{\mathrm{a}}$ & $26.8^{b}$ & $26.3^{c}$ & $26.2^{c}$ & $26.4^{c}$ & $25.3^{d}$ & $25.2^{\mathrm{d}}$ & $25.4^{d}$ & $25.1^{d}$ & 0.07 & $<0.05$ & $<0.05$ & $<0.05$ \\
\hline Neutrophils $\left(10^{3} / \mathrm{mL}\right)$ & $40.0^{a}$ & $39.8^{b}$ & $39.7^{b c}$ & $39.6^{c}$ & $39.4^{d}$ & $39.3^{e}$ & $39.3^{\text {ef }}$ & $39.3^{\text {ef }}$ & $39.2^{f}$ & 0.02 & $<0.05$ & $<0.05$ & $<0.05$ \\
\hline Lymphocytes $\left(10^{3} / \mathrm{mL}\right)$ & $55.8^{\mathrm{a}}$ & $54.9^{b}$ & $54.8^{c}$ & $54.8^{c}$ & $54.8^{c}$ & $54.7^{d}$ & $54.7^{d}$ & $54.6^{e}$ & $54.5^{\dagger}$ & 0.01 & $<0.05$ & $<0.05$ & $<0.05$ \\
\hline Monocytes $\left(10^{3} / \mathrm{mL}\right)$ & $6.75^{\mathrm{a}}$ & $6.61^{c}$ & $6.61^{c}$ & $6.55^{d}$ & $6.54^{d}$ & $6.63^{c}$ & $6.28^{a}$ & $6.71^{\mathrm{ab}}$ & $6.65^{b c}$ & 0.012 & $<0.05$ & $<0.05$ & $<0.05$ \\
\hline Eosinophils $\left(10^{3} / \mathrm{mL}\right)$ & $9.78^{a}$ & $9.71^{\mathrm{b}}$ & $9.58^{c}$ & $8.11^{\dagger}$ & $7.92^{9}$ & $8.41^{d}$ & $8.33^{e}$ & $8.46^{d}$ & $8.32^{\mathrm{e}}$ & 0.013 & $<0.05$ & $<0.05$ & $<0.05$ \\
\hline Basophils $10^{3} / \mathrm{mL}$ & $9.38^{a}$ & $7.51^{\dagger}$ & $7.48^{f}$ & $9.25^{\mathrm{ab}}$ & $9.05^{b c}$ & $8.51^{d}$ & $8.18^{e}$ & $8.82^{c}$ & $8.07^{e}$ & 0.057 & $<0.05$ & $<0.05$ & $<0.05$ \\
\hline Heterophil/lymphocyte ratio & $0.50^{\mathrm{a}}$ & $0.49^{b}$ & $0.48^{b c}$ & $0.48^{c}$ & $0.48^{c}$ & $0.47^{d}$ & $0.46^{d}$ & $0.46^{d}$ & $0.46^{d}$ & 0.002 & $<0.05$ & $<0.05$ & $<0.05$ \\
\hline Red blood cells $\left(10^{6} / \mathrm{mL}\right)$ & $3.15^{h}$ & $3.28^{9}$ & $3.55^{f}$ & $3.84^{\mathrm{e}}$ & $4.17^{d}$ & $4.34^{c}$ & $4.53^{b}$ & $4.61^{b}$ & $4.92^{\mathrm{a}}$ & 0.019 & $<0.05$ & $<0.05$ & $<0.05$ \\
\hline Haemoglobin (HB) (g/dL) & $12.1^{9}$ & $12.9^{f}$ & $13.0^{\mathrm{e}}$ & $13.1^{\text {de }}$ & $13.2^{\mathrm{d}}$ & $13.5^{c}$ & $14.0^{\mathrm{b}}$ & $14.0^{\mathrm{b}}$ & $14.2^{\mathrm{a}}$ & 0.03 & $<0.05$ & $<0.05$ & $<0.05$ \\
\hline $\begin{array}{l}\text { Mean corpuscular HB } \\
\text { concentration }(\mathrm{g} / \mathrm{dL})\end{array}$ & $36.6^{\mathrm{e}}$ & $36.9^{d}$ & $37.1^{c}$ & $37.1^{c}$ & $37.2^{c}$ & $37.3^{\mathrm{b}}$ & $37.4^{\mathrm{b}}$ & $37.4^{\mathrm{ab}}$ & $37.5^{\mathrm{a}}$ & 0.02 & $<0.05$ & $<0.05$ & $<0.05$ \\
\hline
\end{tabular}

OE-250C and OE-500C: control diet supplemented with 250 or $500 \mathrm{mg} / \mathrm{kg}$ of vitamin C. $250 \mathrm{E}-0 \mathrm{C}$ and $500 \mathrm{E}-0 \mathrm{C}$ : control diet supplemented with $250 \mathrm{or} 500 \mathrm{mg} / \mathrm{kg}$ of vitamin $\mathrm{E}$. 250E-250C, 250E-500C, 500E-250C, 500E-500C: control diet supplemented with $250 \mathrm{mg} / \mathrm{kg}$ of both vitamins E and C, 250 and $500 \mathrm{mg} / \mathrm{kg}$ of vitamins E and C, 500 and $250 \mathrm{mg} /$ $\mathrm{kg}$ of vitamins $\mathrm{E}$ and $\mathrm{C}$, and $500 \mathrm{mg} / \mathrm{kg}$ of both vitamins $\mathrm{E}$ and $\mathrm{C}$, respectively.

SEM: standard error of the mean.

For each parameter, least squares means without a common superscript are significantly different $(p<0.05)$ between treatments by Tukey's test.

lymphocytes, monocytes, eosinophils and basophils, the highest ratio of heterophils to lymphocytes and the lowest red blood cell count, haemoglobin concentration and mean corpuscular haemoglobin concentration were found in the control treatment $(p<0.05)$, while the $500 \mathrm{E}-500 \mathrm{C}$ treatment showed the most favourable values on average followed by the 500E-250C and 250E-500C treatments. Increasing the level of vitamin C from 250 to $500 \mathrm{mg} / \mathrm{kg}$ was only able to reduce leukocyte count when combined with $500 \mathrm{mg} / \mathrm{kg}$ of vitamin $\mathrm{E}$, whereas the eosinophil count was decreased $(p<0.05)$ and the red blood cell count and the haemoglobin concentration were raised $(p<0.05)$ regardless of the level of vitamin $E$. Increasing the level of vitamin E from 250 to 500 $\mathrm{mg} / \mathrm{kg}$ increased leukocyte count and decreased neutrophil count when supplemented alone $(p<0.05)$, but not when supplemented together with vitamin $C$ ( $p>0.05)$, while, on the contrary, lymphocyte count was diminished and haemoglobin concentration was increased $(p<0.05)$ only when the level was augmented in the presence of vitamin $C$. Raising the level of vitamin $E$ increased red blood cell count irrespective of the vitamin $C$ level $(p<0.05)$. With regard to the observed changes in leukocyte counts, it is well-known that vitamin supplementation protects immune cells from oxidative damage (Maggini et al., 2007), while a low heterophil to lymphocyte ratio is indicative of ameliorated stress in poultry (Ipek et al., 2007; Şenay et al., 2019). The observed increase of red blood cell counts after vitamin supplementation may be indicative of a lower oxidative stress in red blood cells (Mohanty et al., 2014).

The combination of vitamins $E$ and $C$ had greater positive effects on growth performance, metabolism indicators and haematological parameters of Japanese quail than their supplementation separately. The observed results could be related to an inhibition of corticosteroid release and suggest that the supplementation with vitamins $E$ and $C$ is advantageous even in the absence of any specific stressor other than typical on-farm rearing conditions.

\section{ACKNOWLEDGMENTS}

Financial support by Rasht Branch, Islamic Azad University, grant number 17.16.4.8774, is gratefully acknowledged.

\section{REFERENCES}

Cantatore FP, Loperfido MC, Magli DM, Mancini L, Carrozzo M. The importance of vitamin $C$ for hydroxylation of vitamin D3 to 1,25 $(\mathrm{OH})$ 2D3 in man. Clinical Rheumatology 1991;10:162-167.

Ferit Gursu M, Onderci M, Gulcu F, Sahin K. Effects of vitamin C and folic acid supplementation on serum paraoxonase activity and metabolites induced by heat stress in vivo. Nutrition Research 2004;24:157-164.

Ferit Gursu, M, Sahin, N, Kucuk, O. Effects of vitamin E and selenium on thyroid status, adrenocorticotropin hormone, and blood serum metabolite and mineral concentrations of Japanese quails reared under heat stress $\left(34^{\circ} \mathrm{C}\right)$. Journal of Trace Elements in Experimental Medicine 2003; 16:95-104. 
Imik H, Ozkanlar S, Kaynar O, Koc M. Effects of vitamin E, C, and $\alpha$-lipoic acid supplementation on the serum glucose, lipid profile, and proteins in quails under heat stress. Bulletin of the Veterinary Institute in Pulawy 2009;53:521-526.

Ipek H, Avci M, Yerturk M, Iriada M, Aydilek N. Effects of ascorbic acid and vitamin $\mathrm{E}$ on performance and hematological parameters of Japanese quails under high ambient temperature in Sanliurfa. Archiv fur Geflugelkunde 2007;71:130-134.

Ipek A, Canbolat O, Karabulut A. The effect of vitamin $\mathrm{E}$ and vitamin $\mathrm{C}$ on the performance of Japanese quails (Coturnix coturnix Japonica) reared under heat stress during growth and egg production period. AsianAustralasian Journal of Animal Sciences 2006;20:252-256.

Jang IS, Ko YH, Moon YS, Sohn SH. Effects of vitamin C or E on the proinflammatory cytokines, heat shock protein 70 and antioxidant status in broiler chicks under summer conditions. Asian-Australasian Journal of Animal Sciences 2014;27:749-756.

Khan RU, Naz S, Nikousefat Z, Tufarelli V, Javdani M, Rana N, et al. Effect of vitamin $E$ in heat-stressed poultry. World's Poultry Science Journal 2011;67:469-478.

Khan RU, Naz S, Vnikousefat Z, Selvaggi M, Laudadio V, Tufarelli V. Effect of ascorbic acid in heat-stressed poultry. World's Poultry Science Journal 2012;68:477-490.

Maggini S, Wintergerst ES, Beveridge S, Hornig DH. Selected vitamins and trace elements support immune function by strengthening epithelial barriers and cellular and humoral immune responses. British Journal of Nutrition 2007;98:29-35.

Min YN, Niu ZY, Sun TT, Wang ZP, Jiao PX, Zi BB, et al. Vitamin E and vitamin $C$ supplementation improves antioxidant status and immune function in oxidative-stressed breeder roosters by up-regulating expression of GSH-Px gene. Poultry Science 2018;97:1238-1244.

Mohanty J, Nagababu E, Rifkind JM. Red blood cell oxidative stress impairs oxygen delivery and induces red blood cell aging. Frontiers in Physiology 2014;5:84.
Norazlina M, Ng FW, Ima-Nirwana S. Gamma-tocotrienol is required for normal vitamin $D$ metabolism in female rats. Indian Journal of Pharmacology 2005;37:309-314.

Sahin K, Kucuk O, Sahin N, Sari M. Effects of vitamin C and vitamin E on lipid peroxidation status, serum hormone, metabolite, and mineral concentrations of Japanese quails reared under heat stress $\left(34^{\circ} \mathrm{C}\right)$. International Journal for Vitamin and Nutrition Research 2002;72:91100.

Sahin N, Sahin K, Onderci M, Ozcelik M, Smith MO. In vivo antioxidant properties of vitamin $\mathrm{E}$ and chromium in cold-stressed Japanese quails. Archives of Animal Nutrition 2003;57:207-215.

Scanes CG. Biology of stress in poultry with emphasis on glucocorticoids and the heterophil to lymphocyte ratio. Poultry Science 2016;95:22082215.

Şenay S, Islim P, Tugay A. Supplementation of natural antioxidants to reduced crude protein diets for japanese quails exposed to heat stress. Brazilian Journal of Poultry Science 2019;21:1-14.

Seyrek K, Yenisey C, Serter M, Kargin Kiral F, Alkim Ulutas P, Bardakcioglu HE. Effects of dietary vitamin C supplementation on some serum biochemical parameters of laying Japanese quails exposed to heat stress (34.8 $8^{\circ}$ ). Revue de Médecine Vétérinaire 2004;155:339-342.

Shah AA, Khan MS, Khan S, Ahmad N, Alhidary IA, Khan RU, Shao T. Effect of different levels of alpha tocopherol on performance traits, serum antioxidant enzymes, and trace elements in Japanese quail (Coturnix coturnix japonica) under low ambient temperature. Revista Brasileira de Zootecnia 2016;45:622-626.

Sigolo S, Khazaei R, Seidavi A, Gallo A, Prandini A. Effects of supranutritional levels of vitamin $E$ and vitamin $C$ on growth performance and egg production traits of Japanese quails. Italian Journal of Animal Science 2019;18:480-487.

Virden WS, Kidd MT. Physiological stress in broilers: ramifications on nutrient digestibility and responses. Journal of Applied Poultry Research 2009:18:338-347 